\title{
CSR in Developing Countries: Case Study in Vietnam
}

\author{
PHAN VAN THANH \\ University of Kaposvar, Hungary \\ thanhpv.hut@gmail.com \\ SZILÁRD PODRUZSIK \\ Corvinus University of Budapest, Hungary \\ szilard.podruzsik@uni-corvinus.hu
}

This article provides a review of the practice of corporate social responsibility (CSR) in Vietnamese enterprises, especially in Vietnamese small and medium enterprises (SMES). To do so, this article first reviewed the conceptual framework of CSR and CSR in developing countries. In addition to enhancing the competitiveness of Vietnamese enterprises in general, Vietnamese SMEs in particular, this study highlights the lessons learned from cSR empirical studies in developing countries. Furthermore, based on the analysis of Vietnamese enterprises and csR practices in Vietnam, the article collates the recommendations given by researchers to strengthen and improve the implementation of cSR in Vietnam as well as provide some suggestions to help Vietnamese enterprises get success in applying cSR in their sustainable business objectives. This article concludes the implementation of CSR in Vietnam is still limited, and there are many obstacles and limitations in applying cSR not only from the business itself but also from the operating environment. Therefore, to implement and integrate cSR into Vietnamese enterprises' business strategies, CSR awareness should be improved as well as the legal framework for implementing CSR.

Key words: Corporate Social Responsibility, cSR, Developing Countries, Vietnam, Vietnamese smes

https://doi.org/10.26493/1854-4231.13.287-300

\section{Introduction}

Since corporate social responsibility (CSR) first emerged from the seminal work of Bowen in 1953, it has attracted increasing attention of either scholar, social organizations, and governments or other stakeholders both in developed and developing countries (Ali, Frynas, and Mahmood 2017). In developed countries, CSR activities have received cumulative attention from businesses, which is united into the business strategy of the business. CSR is cogitated a key factor 
for sustainable growth and improved profitability. While, it is hard to apply CSR in developing countries since their legal system is partial and monopoly, corruption, and group interests toughly influence society.

In Vietnam, a developing country, many big companies are aware that in order to grow sustainably, organizations must adhere to the principles of environmental protection, gender equality, equal pay, labour safety, labour rights, talent management, and community growth. They implemented hundreds of actions; such as saving energy, using recycled materials, reducing carbon emissions, or some donation as the school building, help sufferers of natural disasters. There are some ongoing cSR activities, such as Pratham Books (Creating an open-sourced platform for translating books); and GiveDirectly (Creating opportunity through mobile cash transfers) implementing by Google; Since 2006, 'Microsoft company has had an official commitment to regard human rights as a signatory of the United Nations Global Compact' (Dudovskiy 2017). However, with more than 97 percent of registered enterprises are small and medium enterprises (SMES) (Shinozaki 2012). The implementation and application of CSR in Vietnamese enterprises are facing many difficulties and limitations. Because of the limited by the financial resources, personnel, size of the business, in most cases the business owner is also the director (Nguyen et al. 2015). Moreover, Vietnamese SMEs focus more on maximizing profits than on social responsibility.

Recent studies concluded that smes are playing an essential role in the national economy, especially in Vietnam. According to the report of the Asian Development Bank, Vietnamese smes account for up to 97.4 percent of all registered firms. They account for 77.3 percent of the country's total labour force and contribute 26 percent of Vietnam's GDP (Shinozaki 2012). Furthermore, recent researches have shown that CSR benefits both business and society, both large and small and medium enterprises (Udayasankar 2007). According to recent studies, CSR capabilities are defined as a company's knowledge, skills, and processes linked to the planning, implementation, and assessment of CSR initiatives (Lee, Park, and Lee 2013). Such cSR capabilities could be one of the most critical strategic approaches in a company's CSR efforts. CSR helps to improve the image and reputation of the business; increase sale volumes; increase employee motivation, increase attractiveness to potential recruits, etc. (Jenkins 2006; Dzansi 2011).

To achieve the objective of sustainable development, Vietnamese

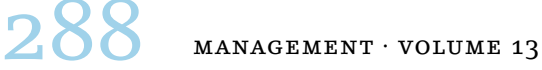


enterprises are not only complying with government mandated standards of employment, environment, and society, but also active with social responsibility which is not regulated by law. Because of new perceptions, many large enterprises in Vietnam have put CSR on the top priority to integrate into their business strategy. Similarly, Vietnamese SMES also have to develop and integrate CSR into their business strategy. However, awareness of CSR and their CSR activities are inadequate. Thus, the main goal of this article is to give a descriptive analysis of the practices of CSR in Vietnam, especially in Vietnamese SMES based on available literature and published data.

\section{Theoretical Background}

CORPORATE SOCIAL RESPONSIBILITY

Since its first appearance in 1953, the cSR concept has had more than 60 years of history. However, it is still complex and complicated. It is complex not only because of the nature and context of the problems, but it is also complicated by four distinct agendas which are engaged in the definitional enterprise (Sheehy 2015). There can be identified numerous attempts in the literature to define CSR. Many scholars have attempted to develop csR concepts such as Carroll (1979; 1999), Wood (1991), Van Marrewijk (2003), Dahlsrud (2008). However, the authors have not reached the consensus about CSR definition as CSR varies in context, content, process, and value. The early definition of CSR more often referred to social responsibility than to CSR, 'It refers to the obligations of businessmen to pursue those policies, to make those decisions, or to follow those lines of action which are desirable in terms of the objectives and values of our society' (Bowen 1953). In the paper published in 1979, Archie Carroll proposed a four-part definition of CSR: 'The social responsibility of business encompasses the economic, legal, ethical and discretionary expectations that society has of organization at a given point in time' (Carroll 1979). In another paper published in 1991, the pyramid of CSR that was introduced by Carroll is one of the earliest efforts to combine the economic and social responsibilities of the corporation (Carroll 1991).

In another study, conducted by Dahlsrud, csR definitions could be categorized by five dimensions, including Environmental; Social; Economic; Stakeholder; and Voluntariness (Dahlsrud 2008). Dahlsrud (2008) also pointed to the definition of CSR with the highest frequency counts from Google to the Commission of the European Communities, which defined csR as 'A concept whereby companies 
integrate social and environmental concerns in their business operations and in their interaction with their stakeholders on a voluntary basis' (European Commission 2002). The rest of the 37 analytical definitions in Dahlsrud's (2008) study refer to four, three, two or even just one dimensions of CSR. However, in the recent review article, Wang and Gao (2016) summarized the definition of csR into four common perspectives, including:

1. An integrative perspective, namely, those definitions generated from a spectrum of views ranging from stakeholder concerns to social issues;

2. An economic perspective, espoused by those researchers who believe that the aim of CSR activities is the maximization of profit, which emphasizes the benefits to shareholders and internal stakeholders;

3. A voluntary perspective, espoused by those researchers who believe that firms should take some philanthropic action in accordance with local laws to improve social welfare;

4. A public perspective, where scholars argue that a CSR strategy should be designed to fit the social system.

Hence, it can be stated that CSR is more than charity and philanthropy. CSR is the commitment of enterprises to integrate social and environmental responsibility into their business operations to improve the quality of life of stakeholders. CSR is 'the continuing commitment by business to contribute to the economic development while improving the quality of life of the workforce and their families as well as of the community and society at large' (WBSCD 2000). CSR is about creating business and social value, about aligning and balancing shareholder, about societal and environmental interests. CSR is defined as the method through which a business achieves a balance of economic, environmental, and social requirements while at the same time addresses the expectation of shareholders and stakeholders (UNIDO 2010). An effective CSR strategy balances the interests of shareholders, society, and the planet, making businesses stronger and more sustainable.

\section{CSR IN DEVELOPING COUNTRIES}

A difference between the high interests with the concept of CSR in general, there is a limited systematic review of the concept of CSR in developing countries to date. The unique elements of CSR in developing countries have been referred to the literature, with cSR commonly characterized as less formalized, more sunken and more phil- 
anthropic (Jamali and Neville 2011). Research by Ali, Frynas, and Mahmood (2017) concluded that the cSR report received different attention from stakeholders in developed and developing countries. Interested stakeholders in developed countries are usually shareholders, regulators, creditors, investors, environmentalists and the media, while in developing countries they are international buyers, foreign investors, international media and international regulatory bodies such as World Bank. Moreover, in contrast to developed countries, companies in developing nations receive relatively lower pressures in the publication of CSR reports.

In another context, a study by Jamali and Mirshak (2007) shows that economic and legal factors are receiving more interest in developing countries in pursuing CSR. This study also concludes that CSR in developing countries is very different from developed countries because of the weak institutional environment emphasized by arbitrary law enforcement, bureaucracy inconsistency, insecurity of property rights and corruption. Operating in a situation like this, a company that strictly enforces rules and regulations can be considered a responsible company. Further enhancing the need to explore CSR in developing countries is a different argument against the possibility of converting the frameworks and conclusions drawn from developed countries into developing countries (Idemudia 2011).

Raynard and Forstater (2002) stated that CSR imposes new demands on SMEs in developing countries. Social and environmental principles are progressively a precondition for doing business with transnational corporations. This is expressed regarding individual supply chain codes of conduct and certification programs across the industry. Market change can increase the impact of environmental and social concerns beyond issues directly related to transnational corporations. This can happen through local competition, by strengthening the mechanism to ensure compliance with local law, by targeting investment or through changing consumer demand. Therefore, CSR needs to be integrated into core business strategies. If this is done, it can still be strong, even if the CSR is a vulnerable charity allowance to cut costs. The long-term success of CSR will be based on its ability to be at the core of its business and development strategy, thereby becoming part of 'business as usual.'

In Vietnam, a developing country, there is limited theoretical and empirical contributions to CSR to date. According to Nguyen (2013), CSR is understood as the enterprise commitments to contribute to the sustainable economic development, through improving living quality of labourers, of their own families, of the community and of the 
TABLE 1 SME in East and Southeast Asia

\begin{tabular}{llccr}
\hline Region & Country & $(1)$ & $(2)$ & $(3)$ \\
\hline East Asia & Japan & 99.7 & 69.4 & 47.7 \\
& Korea & 99.9 & 87.7 & 47.6 \\
& China & 99.0 & 75.0 & 58.5 \\
\hline Southeast Asia & Brunei & 98.4 & 58.0 & 22.0 \\
& Cambodia & 98.5 & - & 85.0 \\
& Indonesia & 99.9 & 97.0 & 56.5 \\
& Lao PDR & 99.8 & 83.0 & 6 to 9 \\
& Malaysia & 99.2 & 59.0 & 31.9 \\
& Myanmar & 92.0 & - & - \\
& Philippines & 99.6 & 63.2 & 35.7 \\
& Singapore & 99.4 & 62.3 & 46.3 \\
& Thailand & 99.8 & 78.2 & 36.7 \\
& Vietnam & 97.4 & 77.3 & 26.0 \\
\hline
\end{tabular}

NотеS Column headings are as follows: (1) number of enterprises (\% of total), (2) number of employees (\% of total), (3) contribution to GDP (\%). Adapted from Shinozaki (2012).

whole society, in the way which is beneficial to both the enterprises and the general development of the society. Furthermore, in the context of globalization and international integration, Vietnamese companies will not be able to gain access to the global market if the companies fail to implement their social responsibility effectively. For the purpose of sustainable development, companies must comply with environmental protection standards, gender equality, labour safety, labour rights, equal pay, staff training and community development. Thus, CSR has become one of the essential requirements of Vietnamese companies.

\section{Practices of CSR in Vietnam}

VIETNAMESE ENTERPRISE

In Vietnam, the number of registered enterprises increase on average by 14 percent annually from 2011 to 2016 (figure 1), and most of the registered enterprises are smes (table 1). Besides, recent researches concluded that SMEs are playing a vital role in the national economy, especially in the Vietnamese economy.

In fact, in 2012, Vietnamese SMEs account for 97.4 percent of the total number of registered companies. Smes account for 77.3 percent of the country's total labour force and contribute 26 percent of Vietnam's GDP (Shinozaki 2012). Moreover, in a recent survey by CPA Australia, the institute reported that 90.7 percent of Vietnamese

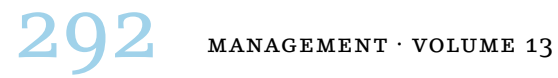




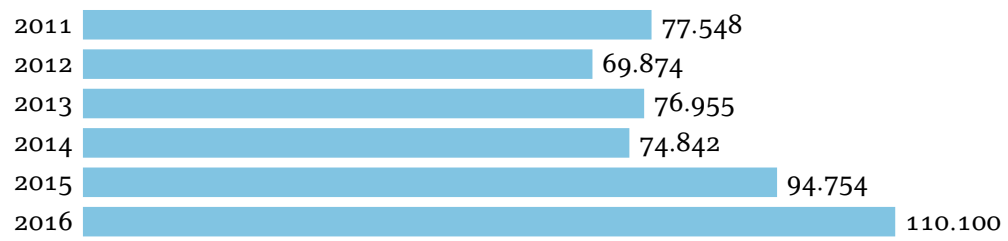

FIGURE 1 Number of Newly Registered Enterprises from 2011-2016 in Vietnam (based on data from http://www.gso.gov.vn)

SMES grew in 2017 and 93.7 percent expect to grow in the next 12 months. While there is only 47.5 percent of Singapore's small businesses reported that they grew in 2017, and 93.4 percent of Indonesian small businesses reported they grew. These figures partly explain the importance of smes to Vietnam's economic development, and the growing interest of domestic and foreign researchers in Vietnamese smes as well.

According to article 6 of the Vietnamese Government's Decree No. 39/2018/ND-CP, 'SMES are business establishments registered in accordance with the law. It is divided into three levels: micro, small and medium scale (the total capital equivalent to the total assets determined in the enterprise's balance sheet or the average labour force is a priority criterion)' (table 2). smes include a very broad range of businesses from traditional family businesses to companies with hundreds of employees.

Vietnamese smes is limited by the financial resources, personnel, size of the business, and usually, the business owner is also the director. They focus more on profit maximization than on social responsibility. However, recent studies implied that cSR benefits both business and society, for both large and smes (Udayasankar 2007). The benefits of implementing CSR in SMES include: improved image and reputation; improved trust and understanding; larger, more prominent profile; better market position; increased sale volumes; increased employer motivation; increased attractiveness to potential recruits; cost savings and increased efficiency; enhanced risk management; benefits for company culture; enhanced customer satisfaction, employee loyalty, etc. (Jenkins 2006; Dzansi 2011).

Therefore, this paper focuses on the analysis of Vietnamese smEs and the practice of cSR in Vietnamese smes in particular and Vietnamese enterprises in general. In the next sections, the article will focus on the implementation of cSR in Vietnam as well as give some recommendations to help Vietnamese enterprises get success in applying CSR in their sustainable business objectives. 
TABLe 2 Sme Criteria by Vietnamese Government's Decree No. 39/2018/ND-CP

\begin{tabular}{|c|c|c|c|c|c|c|}
\hline & \multicolumn{6}{|c|}{ Company Category } \\
\hline & \multicolumn{2}{|c|}{ Micro } & \multicolumn{2}{|c|}{ Small } & \multicolumn{2}{|c|}{ Medium-sized } \\
\hline & (1) & (2) & (1) & (2) & (1) & (2) \\
\hline (i) & $\begin{array}{l}A \leq 3 \text { or } \\
R \leq 3\end{array}$ & $\mathrm{~L} \leq 10$ & $\begin{array}{l}A \leq 20 \text { or } \\
R \leq 50\end{array}$ & $\begin{array}{l}10<\mathrm{L} \leq \\
100\end{array}$ & $\begin{array}{l}A \leq 100 \text { or } \\
R \leq 200\end{array}$ & $\begin{array}{l}100<\mathrm{L} \leq \\
200\end{array}$ \\
\hline (ii) & $\begin{array}{l}A \leq 3 \text { or } \\
R \leq 3\end{array}$ & $\mathrm{~L} \leq 10$ & $\begin{array}{l}A \leq 20 \text { or } \\
R \leq 50\end{array}$ & $\begin{array}{l}10<\mathrm{L} \leq \\
100\end{array}$ & $\begin{array}{l}A \leq 100 \text { or } \\
R \leq 200\end{array}$ & $\begin{array}{l}100<\mathrm{L} \leq \\
200\end{array}$ \\
\hline (iii) & $\begin{array}{l}A \leq 3 \text { or } \\
R \leq 10\end{array}$ & $\mathrm{~L} \leq 10$ & $\begin{array}{l}A \leq 50 \text { or } \\
R \leq 100\end{array}$ & $10<\mathrm{L} \leq 50$ & $\begin{array}{l}A \leq 100 \text { or } \\
R \leq 300\end{array}$ & $\begin{array}{l}50<\mathrm{L} \leq \\
100\end{array}$ \\
\hline
\end{tabular}

nотеS Column headings are as follows: (1) Total assets and total revenue of the year (billion VND), (2) the average number of employees participating in social insurance of the year. Row headings are as follows: (i) agriculture, forestry and fisheries, (ii) industry and construction, (iii) trade and services.

\section{CSR IN VIETNAM}

According to data collected from secondary sources in Vietnam and abroad. It is can be said that there are three milestones in the history of CSR in Vietnam, including:

- First, in 200os CSR has been introduced in Vietnam through the operation of the multinational companies investing in Vietnam, for example, Honda-Vietnam, Coca-Cola Vietnam, UnileverVietnam, Microsoft, HP ... These companies commonly develop the Code of Conduct and standards of business culture which are universal in order to apply in various geographical markets (Nguyen et al. 2015). A number of successful cSR programs at the time were launched, such as 'I love Vietnam' program of Honda Vietnam in 2004; Vision rehabilitation program for poor children of Western Union in 2004; Coca-Cola Vietnam began the Clean Water for Communities project in 2006. UnileverVietnam began the Protection Vietnamese Smile program in 1998, Sanitation program for children in mountainous provinces in 2007; Program for the Development of Sustainable Community Informatics Centers in 64 Provinces of Vietnam (торіс64), sponsored by Microsoft, Qualcomm, Hewlett Packard and USAID from 2006; The program supports congenital malformations and support for victims of Can Tho bridge collapse of VinaCapital and Samsung in 2007.

- Second, in 2005, the Vietnamese government also started to encourage companies to protect the environment and improve working conditions. They issued new rules for sustainable development, typical of this are Agenda 21 and the new Law of

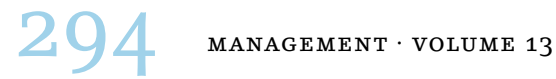


Environmental Protection. Environmental police have been set up to take measures to stop polluting companies, and companies will be subject to separate penalties for contaminated sewage. With the support of the Vietnam Chamber of Commerce and Industry (vcCI), the Vietnam Business Linking Initiative (VBLI) has established close relationships with NGOS, other international organizations as well as businesses using foreign capital. Thanks to this program, smes shoe manufacturers and industrial textiles can participate in training programs or consultancy services as well as enhance awareness of CSR knowledge. The most important event in 2005 was that vBLI started awarding 'CSR Awards' to the most committed businesses. Some typical programs such as ' $\mathrm{P} / \mathrm{s}$ protect Vietnamese smile' program of Unilever-Vietnam; ' 6 million glasses of milk for Vietnamese children' program implemented by Vinamilk; Scholarship fund 'firefly lights' established by Dutch Lady.

- Third, 2010 marked the change in awareness of Vietnamese enterprises, especially Vietnamese SMES. Thanks to the EU-funded project 'Helping Vietnamese smes Adapt \& Adopt cSR for Improved Linkages with Global Supply Chains in Sustainable', implemented in Vietnam by the United Nations Industrial Development Organization (UNIDO) from 2010 to 2013. There are many Vietnamese SMES are trained and updated their cSR knowledge through training sessions or seminars. According to the surveys that conducted by Taylor Nelson Sofres Viet Nam in 2013, it can be concluded that there is clear evidence of increased awareness about, understanding and practice of CSR in the sector of SMES within the time period of the UNIDo's project in Vietnam (table 3) (UNIDO 2013).

In another context, some recent studies concluded that Vietnamese enterprises which have integrated CSR into their business strategy regularly are multinational, large or export companies. Meanwhile, many SMEs in Vietnam are not fully aware of CSR, not aware of the benefits and opportunities that CSR can bring to the business. They frequently focus only on exploiting the resources available to maximize profits but forget the interests of customers, responsibility to labourers, to eco-environment, to the community and the future generations (Nguyen et al. 2015).

According to a study conducted by World Bank in Vietnam, the biggest barriers and challenges to the implementation of CSR of enterprises are: 
TABLE 3 CSR Awareness Score Distribution of Vietnamese SMES

\begin{tabular}{|c|c|c|c|c|c|c|c|c|}
\hline \multirow{2}{*}{$\begin{array}{l}\text { Range of } \\
\text { awareness } \\
\text { score* }^{*}\end{array}$} & \multicolumn{2}{|c|}{ Total } & \multicolumn{2}{|c|}{$\begin{array}{c}\text { Textiles and } \\
\text { garment }\end{array}$} & \multicolumn{2}{|c|}{$\begin{array}{c}\text { Leather and } \\
\text { footwear }\end{array}$} & \multicolumn{2}{|c|}{ Electronics } \\
\hline & (1) & (2) & (1) & (2) & (1) & (2) & (1) & (2) \\
\hline$<10$ & 0.3 & 0.0 & 0.0 & 0.0 & 0.6 & 0.0 & 0.0 & 0.0 \\
\hline $11-20$ & 0.6 & 0.0 & 0.5 & 0.0 & 0.6 & 0.0 & 0.0 & 0.0 \\
\hline $21-30$ & 3.7 & 2.9 & 4.1 & 2.5 & 3.1 & 2.4 & 2.0 & 2.4 \\
\hline $31-40$ & 14.8 & 17.8 & 16.8 & 18.5 & 14.0 & 17.0 & 8.0 & 14.6 \\
\hline $41-50$ & $53 \cdot 3$ & 60.1 & 50.7 & 56.0 & 53.8 & 64.5 & 60.0 & 58.6 \\
\hline$>51$ & 28.4 & 20.5 & 28.0 & 22.5 & 27.6 & 16.4 & 30.0 & $24 \cdot 3$ \\
\hline
\end{tabular}

Notes * The higher scores the higher awareness. Scores based on the answers (corresponds to values from o to 3) that each respondent gave to each statement. Each respondent could get a score between o (if a respondent said that all 20 statements were not at all important) and 60 (if a respondent said that all 20 statements were very important). (1) 'Baseline' and (2) 'End-line' refer to the year when the survey was conducted on the similar sample of 400 SMES, in 2009 and 2013, respectively. Adapted from UnIDo (2013).

- Insufficient awareness of the concept of social responsibility within and between corporates in Vietnam;

- Productivity being affected when performing multiple sets of Codes of Conduct synchronously;

- Lack of financial and technical resources for the implementation of social responsibility standards (especially for SMEs);

- Confusion for corporates due to differences between Code of Conduct and the Labour Code;

- cSR activities that have been implemented without transparency are hindering benefits brought by potential markets to businesses;

- State's regulations affect the results of the implementation of the code of conduct; and

- The habits in consumer culture have not promoted the role of customers in protecting products of corporates that have well implemented social responsibility as well as the fighting spirit against corporate with commercial frauds.

In fact, today's csR activities in Vietnam focus on some successful programs implemented by multinational companies such as HondaVietnam, Coca-Cola Vietnam, Unilever-Vietnam, Microsoft, HP ... CSR activities of Vietnamese SMES, if any, are only charitable activities for some individuals or communities where the business operates. Moreover, besides the 'good programs' as mentioned above, there have been many 'bad activities' - cases of business ethics vio- 
lations, severe environmental and human health violations. For example, the most serious recent incident has been the Vietnam sea catastrophe in 2016, which is a water pollution crisis that has affected central provinces of Vietnam - The Formosa steel plant is suspected to be the source of the toxic chemical waste; or some typical incidents have happened in the past, such as milk containing birth control drug, melamine of China; industrial alcohol made fatal to consumers; poor quality counterfeit fertilizers; soya source containing 3-MCPD; growth stimulators passed on cattle through animal feed are not fully resolved; direct discharge of untreated sewage into Vedan's Thi Vai River in Vietnam ... This is due to the lack of awareness of CSR that has serious consequences for the environment, society, and consumers (Nguyen and Duc 2008).

Also, due to the lack of social responsibility regulations from the government, the Vietnamese mechanisms and punishments are not sufficient to prevent enterprises from violating the law, as a result, many enterprises do not care about these lawsuits. There have been many cases of violations that have been identified but also difficult to resolve, such as the controversy over the sanctioning form of Vedan in 2008 or the recent matter of Formosa Ha Tinh in 2016 (Phan and Szilárd 2017). Similarly, in October 2008, Vinh Long province detected 11 companies producing poor quality fertilizers, of which the useful ingredient was almost zero. However, these companies were fined only a total of VND 130 million. Obviously, fines are too small compared to the profits earned from fraud, as well as its impact on farmers.

\section{Conclusions}

CSR in developing countries has evolved into a significant body of scholarship that retains its nuances, peculiarities, and distinctiveness as a platform for knowledge generation (Jamali and Karam 2016). However, the implementation of CSR in developing countries is still limited. Especially in Vietnam, a developing country, the implementation of CSR also encountered many obstacles and limitations. These obstacles and limitations come not only from the business itself but also from the operating environment. For example, Vietnamese SMES focus more on maximizing profits than on social responsibility. Furthermore, they lack awareness of CSR, lack of financial and technical resources for the implementation of social responsibility standards.

Furthermore, the Vietnamese legal system is incomplete, and monopoly, corruption, and group interests strongly influence soci- 
ety. Furthermore, there are limitations of social responsibility regulations from the government, the Vietnamese mechanisms and punishments are not sufficient to prevent enterprises from violating the law. Therefore, to implement and integrate CSR into Vietnamese enterprises' business strategies, CSR awareness should be improved as well as the legal framework for implementing CSR. Further research could identify factors that motivate Vietnamese SMEs to fulfil their social responsibilities as well as to determine the impact of CSR on the business performance.

\section{References}

Ali, W., J. G. Frynas, and Z. Mahmood. 2017. 'Determinants of Corporate Social Responsibility (CSR) Disclosure in Developed and Developing Countries: A Literature Review.' Corporate Social Responsibility and Environmental Management 27 (4): 273-94.

Bowen, H. R. 1953. Social Responsibilities of Businessman. New York: Harper \& Brothers.

Carroll, A. B. 1979. 'A Three-Dimensional Conceptual Model of Corporate Performance.' Academy of Management Review 4 (4): 497-505.

- 1991. 'The Pyramid of Corporate Social Responsibility: Toward the Moral Management of Organizational Stakeholders.' Business Horizons 34:39-48.

- 1999. 'Corporate Social Responsibility Evolution of a Definiton Construct.' Business \& Society 38 (3): 268-95.

Dahlsrud, A. 2008. 'How Corporate Social Responsibility Is Defined: An Analysis of 37 Definitions.' Corporate Social Responsibility and Environmental Management 15 (1): 1-13. https://doi.org/10.1002/csr

Dudovskiy, J. 2017. 'Microsoft Corporate Social Responsibility (cSR).' 2017. https://research-methodology.net/microsoft-corporate-socialresponsibility-csr/

Dzansi, D. Y. 2011. 'Social Responsibility of Small Businesses in a Typical Rural African Setting: Some Insights from a South African Study.' African Journal of Business Management 5 (14): 5710-23.

European Commission. 2002. 'Corporate Social Responsibility: A Business Contribution to Sustainable Development.' сом(2002) 347 final, European Commission, Brussels.

Idemudia, U. 2011. 'Corporate Social Responsibility and Developing Countries?' Progress in Development Studies 11 (1): 1-18.

Jamali, D., and C. Karam. 2016. 'Corporate Social Responsibility in Developing Countries as an Emerging Field of Study.' International Journal of Management Reviews 20 (1): 32-61.

Jamali, D., and R. Mirshak. 2007. 'Corporate Social Responsibility (cSR): Theory and Practice in a Developing Country Context.' Journal of Business Ethics 72:243-62.

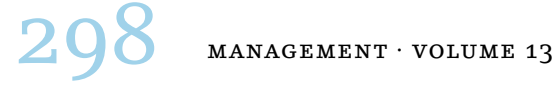


Jamali, D., and B. Neville. 2011. 'Convergence Versus Divergence of CSR in Developing Countries? An Embedded Multi-Layered Institutional Lens.' Journal of Business Ethics 102:599-621.

Jenkins, H. 2006. 'Small Business Champions for Corporate Social Responsibility.' Journal of Business Ethics 67:241-56.

Lee, E. M., S. Y. Park, and H. J. Lee. 2013. 'Employee Perception of cSR Activities: Its Antecedents and Consequences.' Journal of Business Research 66 (10): 1716-24.

Marrewijk, M. V. 2003. 'Concepts and Definitions of csR and Corporate Sustainability: Between Agency and Communion.' Journal of Business Ethics 44:95-105.

Nguyen, N. M. 2013. 'Understanding the Social Responsibility of Korean Businesses in Vietnam (Part 1).' http://cks.inas.gov.vn/index.php ?newsid=323

Nguyen, D. C., and L. M. Duc. 2008. 'cSR: Some of Theoretical Issues and Requirements for State Management of CSR in Vietnam.' Economic Management Review 23:3-11.

Nguyen, T.-V., P.-H. Mai, P.-H. Tran, and V.-P. Nguyen. 2015. 'Current Situation of Corporate Social Responsibility in Vietnam Today.' European Journal of Business and Social Sciences 4 (9): 156-63.

Phan, V.-T., and S. Podruzsik. 2017. 'Corporate Social Responsibility in Vietnamese smes.' Paper presented at the 6th International Conference of Economic Sciences, Kaposvár, 4-5 May.

Raynard, P., and M. Forstater. 2002. 'Corporate Social Responsibility: Implications for Small and Medium Enterprises in Developing Countries.' http://195.130.87.21:8080/dspace/handle/123456789/ 1169

Sheehy, B. 2015. 'Defining csR: Problems and Solutions.' Journal of Business Ethics 131:625-48.

Shinozaki, S. 2012. 'A New Regime of sme Finance in Emerging Asia: Empowering Growth-Oriented smes to Build Resilient National Economies.' ADв Working Paper Series on Regional Economic Integration 104, Asian Development Bank, Mandaluyong.

Udayasankar, K. 2007. 'Corporate Social Responsibility and Firm Size.' Journal of Business Ethics 83:167-75.

UNIDO. 2010. 'Baseline Survey Report 2010: Awareness, Understanding and Usage of Social Corporate Responsibility among Vietnam's Small and Medium Enterprises.' http://www.globalcompactvietnam .org/upload/attach/csR\%2oBaseline\%2oSurvey\%2oEN.pdf

- 2013. 'End of Action Survey: Helping Vietnamese smes to Adapt and Adopt csR for Improved Linkages in Global Supply Chains in Sustainable Production.' http://www.globalcompactvietnam.org/ upload/attach/CSR\%2oEOA\%2oSurvey\%2ocomplete\%2oUNIDO \%202013\%20TNS.pdf

Wang, S., and Y. Gao. 2016. 'What Do We Know about Corporate Social 
Responsibility Research? A Content Analysis.' The Irish Journal of Management 35 (1): 1-16.

wBscD. 2000. 'Corporate Social Responsibility: Making Good Business

Sense.' http://old.wbcsd.org/pages/edocument/edocumentdetails .aspx?id=83\&nosearchcontextkey=true

Wood, D. J. 1991. 'Corporate Social Responsibility Revisited.' Academy of Management Review 16 (4): 691-718.

This paper is published under the terms of the Attribution-

NonCommercial-NoDerivatives 4.o International (CC BY-NC-ND 4.0)

License (http://creativecommons.org/licenses/by-nc-nd/4.o/). 